\title{
Fekete Adrienn: Az egyénközpontú megközelítés története, módszertana, és alkalmazhatósága Magyarországon
}

\begin{abstract}
Absztrakt
Írásom témája az egyénközpontú megközelítés története és módszertana a fogyatékos személyekkel való segítő munka kapcsán. Célom, hogy bemutassam a megközelítés mögött húzódó értékeket és alapelveket, valamint az egyénközpontú tervezés elméletét és gyakorlatát. Mivel hazánkban még nincs példa ennek az eszköznek az alkalmazására, ezért a nemzetközi gyakorlaton keresztül szemléltetem megvalósítását lépésről lépésre. Továbbá azt vizsgálom, hogy milyen nehézségekbe ütközik a módszer magyarországi alkalmazhatósága, és hogyan lehetne a kitagolás során segítségünkre.
\end{abstract}

Kulcs szavak: fogyatékosság, társadalmi változás, egyénközpontú tervezés, intézménytelenítés, normalizáció, MAPS módszer, nemzetközi gyakorlat, módszertan, magyarországi lehetőségek és alkalmazhatóság

\section{Abstract}

This article is about the history and methodology of person-centered planning related social work with people with disabilites. My goal is to present the underlying values and princples of the person-centered theory together with practice. I would like to give some example to the practice from international experiences and articles since we don't use person-centered planning in Hungary (yet). Furthermore I analyze what kind of difficulties we have to consider when we think of using this method in our country, and if it would be possible to apply it during the course of deinstitualization.

Keywords: people with diabilities, social change, person centered planning, deinstutialization, nomralization, MAPS: Action Planning, methodology, inetrnational practice, possibilites in Hungary

A szociális munka alapvetően nem elvont tudomány, hanem gyakorlat központú szakma. Minden nap kliensekkel találkozunk, akiknek megvan a saját élet története, kapcsolati hálója, körülményei, anyagi helyzete és lehetőségei, vagy éppen ezeknek hiánya. Mi, a szakemberek, ezeknek a dimenzióknak a feltérképezése után megpróbáljuk klienseinket belehelyezni a szociális ellátórendszer nyújtotta lehetőségek közé, amelyben kiválasztjuk a számukra nyújtható szolgáltatásokat. Az embereket igazítjuk a rendszerhez, és nem a rendszereket igazítjuk az igényekhez. Ezt általában is elmondhatjuk a magyarországi szociális munkáról, de különösen igaz ez a fogyatékos személyeket ellátó intézményeinkre. De vajon van-e más lehetőségünk, mint elismerni a rendszer gyengeségeit, és a tőlünk telhető legjobbat kihozva magunkból tovább dolgozni? Van-e számunkra alternatíva?

Cikkemben közös gondolkozásra hívom azokat, akik szeretnének még inkább a társadalmi felelősségvállalás és a közösségi kezdeményezések irányába elmozdulni, és az intézmény- és 
rendszerközpontúság kereteiből kilépve szívesen próbálnának ki új módszereket. Bár a 2011ben elkezdődő intézményi kitagolás gondolata is az integrációt erősíti, de nincs egységes konszenzus a szakma képviselöi között. Vannak, akik az intézményi elhelyezést praktikusabbnak, biztonságosabbnak tartják, föleg az intenzív gondozási igényekkel rendelkezők számára, mások viszont épp azt fogalmazzák meg, hogy a gondozási szükséglettel együtt az egyéni szükségletek is nőnek, ami intézményi keretek között sokkal nehezebben valósítható meg (BUGARSZKI és mtarsai, 2011). A két eltérö álláspont mögött rendkívül sok minden húzódhat, jó szándék, féltés, félelem a változástól, vagy csak éppen a megszokás. A nagy intézmények felszámolására, a közösségi lakhatás megteremtésére nemzetközi szinten és hazánkban is egyre több jó példa van. Írásomban egy módszertani eszközt szeretnék bemutatni, ami segítheti a fogyatékos személyek integrációs folyamatainak felgyorsítását különböző társadalmi színtereken, legyen az oktatás, a munka világa vagy tágabb értelemben a közösségi életbe való beilleszkedés.

A módszer megismeréséhez egészen az 1960-as évekbe kell visszatérnünk az USA-ba. Ez az időszak a polgári jog, az öntudatra ébredés időszaka volt az Egyesült Államokban. Az emberekben egyre jobban megerösödött az egyenlőség gondolata. Az egyenlőségnek nemre, fajra, vallási hovatartozásra tekintet nélkül mindenkire érvényes kiterjesztésére. Ebben az időszakban, ennek a politikai és polgári változásnak az égisze alatt megjelent az egyenlő bánásmód és a normalizáció elve, melynek fókuszába az intézményi elhelyezésben lévő fogyatékos és pszichiátriai betegek kerültek. Ennek a kezdeményezésnek legnagyobb erőssége az volt, hogy a szakmai törekvések, szociális szakemberek mellett maguk az érintettek is képviseltették magukat és jogaikat (O'BRIEN és O'BRIEN, 2000).

Öntudatos kliensek, akikkel nehéz mit kezdeni, akik az állam paternalisztikus gondolkodásmódjába nehezen illeszthetők be. A szociális munka bármely területén is dolgozunk, szeretnénk, ha klienseink önálló döntéseket tudnának hozni, de emellett hajlamosak vagyunk azt gondolni, hogy ennek az önállóságnak azzal kell összhangban lennie, amivel mi is, és az ellátórendszer is egyetért.

$\mathrm{Az}$ öntudatos kliensek pedig képesek a világot is megváltoztatni. Olyan erőtartalékokkal rendelkeznek a saját sorsuk megváltoztatására, melyre nekünk, szakembereknek sokszor már nincs kapacitásunk. Erre a megváltoztató erőre jó példa Ed Roberts élete és munkássága, aki 14 éves korában gyermekparalízist kapott, melynek következtében nemcsak végtagjai, de légző izmai felett is elvesztette az irányítást, és egy lélegeztető gépbe (un. Vastüdőbe) kényszerült. Az öngyilkosság gondolata sokszor foglalkoztatta, de életcélt talált. Visszakerült az iskolába, ahol a társai nem tudták, hogy hogy kezeljék ezt a helyzetet. A sajnálkozás és szánalom sok nehéz pillanatot okozott számára. Érettségi után bejutott a Berkeley Egyetemre. Kezdetben rengeteg harca volt az egyetem vezetőségével, a merev szabályokkal, melyek nem voltak tekintettel az életviteléhez szükséges igények betöltésére, de ahelyett, hogy feladta volna, elérte, hogy állapotához képest a legönállóbb, és legkevésbé diszkriminatív módon végezze tanulmányait. Ezt a privilégiumot nem szerette volna saját magának megtartani. Már az egyetem alatt is csatlakoztak hozzá, más fogyatékkal élő társai. Helyi szinten sikerült változásokat elérniük, de ennél is nagyobb, az egész világra kiterjedő hatást tett Önálló Életvitel Mozgalma (KÁLMÁN- KÖNCZEI, 2002). Teljes életet élt, rengeteg ember életére hatással volt és megváltoztatta azt, hogy hogyan tekintünk a fogyatékkal élö emberekre. Egyik interjújában rendkívül fontos dolgot fogalmazott meg: „nagyon kevés olyan fogyatékos személy van, aki semmilyen kontrolt nem képes gyakorolni a saját élete felett, ugyanakkor ezt a társadalom nem is várja el tőlük. Sikerült kiépíteni egy olyan szociális és politikai rendszert, ami nem várja el a fogyatékos személyektől, hogy aktív részt vállaljanak a közösség 
müködésében, pedig sokkal több mindenre képesek lennének, ha teret engednének számukra az aktív részvételben."

\section{Az egyénközpontú megközelítés és annak története}

Az amerikai földrészen az egyénközpontú (person-centered) megközelítés az 1960-as években indult útjára, helyet adva egy teljesen új látásmód megszilárdulásának a fogyatékos személyekkel való munkában. A társadalom perifériája, a nagyintézményi keretek helyett a fogyatékos személyek számára megnyílt az út a társadalmi integráció felé. Az egyénközpontú megközelítés alapvetően nem az intézményekre, hanem a fogyatékos személyre, és az öt körülvevő természetes támaszrendszerre, családra, tágabb közösségre épít. A cél, hogy a közös munka során megerösítsük a fogyatékos személyt abban, hogy értékes tagja a társadalomnak, a közösségnek, amiben él, és az önmaga számára kitűzött és megfogalmazott célok elérhetőek, ha a támaszrendszer, és az elérhető szolgáltatások ebben partnerek.

Magyarországon nem ez az alapvető szemlélet a fogyatékos személyekkel való munka során, de már egyre több jó példát találhatunk arra, hogy alapítványok, non-profit intézmények, állami és egyházi kezdeményezések mozdulnak el ebbe az irányba, és válnak nyitottá ennek elsajátítására. Megkezdődött az „intézménytelenítés”, a nagy intézmények kitagolása, mely számos kérdést felvet, mint például, hogy mivel segíthetjük legjobban a fogyatékos személyek társadalmi integrációját.

$\mathrm{Az}$ egyénközpontú tervezés gondolatával és a MAPS ${ }^{2}$ módszerrel személyesen egy csehországi kis alapítvánnyal találkoztam, mikor az Erasmus program keretében Ostravában töltöttem egészségügyi szociális munka gyakorlatomat. A Centrum Pro Rodina intézményt egy látogatás keretében ismertem meg, ez a hely kifejezetten olyan családokkal foglalkozik, akiknek gyermekei valamilyen fogyatékkal születtek. Miután felvázolták számomra az egyénközpontú megközelítés ideológiáját, és a módszert, mellyel az intézményük szolgáltatásait igénybe vevő családokkal dolgoznak sok kérdés felvetődött bennem ennek a sikerességével kapcsolatban. Ugyanakkor úgy tünt, hogy egy fontos dologra találtam, így megkértem a személyzet tagjait, hogy részletesebben mutassák be a módszer gyakorlati müködését, melyre készséggel igent mondtak. Néhány hónapja dolgoznak csupán a MAPSszel, és nagyon pozitív visszajelzéseket kapnak a fogyatékos személyektől és családjaiktól. Ezeknek a tapasztalatoknak hatására kezdtem el mélyrehatóbban tanulmányozni az egyénközpontú megközelítést és annak eszköztárát, és ennek hatására kezdett el komolyan foglalkoztatni a kérdés, lehet-e ennek létjogosultsága hazánkban.

Az egyénközpontú szemlélet, és annak módszerei kihívást állítanak a fogyatékos személy, a családja, közvetlen környezete és az ellátó rendszer felé, hogy merjenek másként gondolkozni lehetőségekről és képességekről. Magyarországon is rengeteg céltudatos szülő, családtag van, akik szeretnék, ha fogyatékos szeretteik a lehető legteljesebb életet tudnák élni. Úgy gondolom, hogy ezzel eszközt adhatunk mind az ő, mind a szakemberek kezébe. Az egyénközpontú tervezés arra épít, hogy a közösség és a társadalom hatékony szerepvállalása következtében a biológiai funkciózavarok ellenére, a fogyatékos személy teljes, tevékenységekben, és társadalmi részvételben gazdag életet élhet, mely megegyezik a legújabb fogyatékossági definíció által képviselt látásmóddal.

\footnotetext{
${ }^{1}$ Eredeti szöveg (Ed Roberts): http://mn.gov/mnddc/ed-roberts/sixtyMinutes.html

2 MAPS elnevezés a (Making Action Plans v. McGill Action Planning Systems) mozaikszavakból származik. Jelentése: Készítsünk akciótervet vagy más néven: McGill akciótervező rendszere)
} 


\section{Az egyénközpontú tervezés története}

Az állam és az egyház korán, már a 18. század második felében, felismerte felelősségét a fogyatékos személyek gondozásában, de a rehabilitációs munka, a képességek erősítése, visszaállítása, csak az első világháború után vált általános irányzattá. Ennek a folyamatnak a következő állomása a közösségbe való integrálás, az önálló életvitel promóciója a fogyatékos személyek számára. Ez az irányzat a skandináv országokban és az amerikai földrészen már az 1960-as évek folyamán elkezdődött, jogi, politikai lépések is segítették ennek megerösödését, és a fogyatékos személyek esélyegyenlőségért vívott harcát. A huszadik század talán két leghíresebb dokumentuma az 1975. december 9-én ENSZ által elfogadott Egyezmény a fogyatékossággal élő személyek jogairól, mely 13 pontban fedi le az élet minden területére vonatkozó jogaikat. Valamint az 1990. július 6-án aláírt Americans with Disabilities Act, mely a szolgáltatások területére általánosan kiterjeszti a hátrányos megkülönböztetés tilalmát (KÁLMÁN-KÖNCZEI, 2002).

Magyarországon a fogyatékos személyek helyzete ebben az időszakban, a szocialista rendszer alatt egészen más megítélés alá esett. A cél az volt, hogy minél inkább kivegyék őket a társadalomból, nagy vidéki intézményekben biztosítottak számukra ellátást. A meglévő képességeik kibontakoztatása, a személyre szabott segítés gondolata nagyon távol volt mind a szakmai, mind a laikus gondolkozásmódtól. A fogyatékos személyek érdekképviselete is csak a rendszerváltás után, az 1990-es években kezdett kibontakozni. Ennek talán egyik legjelentősebb pontja az 1998. évi XXVI. törvény a fogyatékos személyek jogairól és esélyegyenlőségük biztosításáról, mely életbe lépésével utat nyitott a fogyatékos személyek teljes társadalmi integrációja felé (KÁLMÁN-KÖNCZEI, 2002).

Az önálló életvitel és a közösségbe való integráció gondolatával együtt jelent meg egy új irányzat, ami a gondozás, segélyezés, az állam paternalisztikus segítő intézményei helyett az egyénekre helyezi a hangsúlyt. Ez az egyénközpontú tervezés, melynek célja, hogy az emberek felismerjék, a fogyatékos személy is hasznos tagja a társadalomnak. Ez a felismerés az által lehetséges, ha képesek vagyunk lehetőséget biztosítani arra, hogy valóban azok tudjanak lenni, akik és bevonjuk öket a közösségekbe.

Az egyénközpontú megközelítés gondolatának promóciója a meglévő szolgáltatások tanulmányozásával kezdődött. Vizsgálták az ellátórendszer müködését, különös tekintettel arra, hogy az intézmények és szociális ellátások hogyan hatnak az egyes emberek életére. Rá kellett ébredniük, hogy az intézményesített szolgáltatások csak megerősítik a társadalom és a fogyatékos személyek közötti távolságot, és újratermelik a meglévő elöítéleteket. 1985-re a szakemberek jelentős része számára általánosan elfogadottá vált ez a megközelítés az USAban. Lényege, hogy a fogyatékos személyekkel való munka középpontjába az embert és nem a diagnózist helyezik. A természetes támaszrendszer bevonásával térképezik fel a személy képességeit, készségeit, tehetségét, vágyait, és elérendő célokká alakítják őket. A cél, hogy a szolgáltatások alapját ne az intézményrendszerek fenntarthatósága adja, hanem a szolgáltatásokat használó személyek igényei (O’BRIEN és O’BRIEN, 2000).

1988-ra már több módszert is kidolgoztak, melyeket adaptálni lehetett különböző területek és célok szerint. A munka következö fázisának középpontjában az a kérdés állt, hogyan lehetne általánosan elfogadottá tenni ezt a látásmódot a fogyatékos személyekkel való munkában, és beépíteni azt a mindennapi gyakorlatba. 1986 között jelentek meg azok a szakmai közösségek, akik a normalizáció elvét gyakorolva és alapul véve kezdték el kidolgozni a egyénközpontú tervezés alapjait.

Wolf Wolfensberger a „The Origin and Nature of our Institutional Models” (1969) című könyvében arról ír, hogy a nagy intézmények aláhúzzák és megerősítik a mélyen húzódó 
társadalmi elöítéleteket a fogyatékos személyekkel kapcsolatban, valamint a képessé tevés helyett megteremtik az intézményfüggőséget

Az a gondolkozásmód, hogy a fogyatékos személyeket társadalmi tehernek, és magatehetetlen problémának látjuk, megjelenik az intézményi kultúrában és a számukra biztosított szolgáltatásokban.

Nirje, svéd világpolgár, aki az értelmi fogyatékosok érdekvédelmében hozott jelentős változásokat az 1960-as évektől kezdve az európai kontinensen. Normalizációs elvének 8 pontja a skandináv államokból indult el, ugyanakkor a Nirje a normalizáció gondolatát intézményi keretek között képzelte el. Wolfensberger ezzel ellentétben a normalizáció folyamatával szorosan összetartozónak gondolta a társadalmi befogadás és integráció gondolatát. A közösség tagjainak kell elérhetővé tenniük a fogyatékos személyek számára azt az életvitelt, ami számukra elérhető (O’BRIEN és O’BRIEN, 2000).

Számtalan fogyatékos személy számára nyújtott szolgáltatás nem a kliensek érdekét, fejlődését helyezi a középpontba, hanem azokat a sokszor irreális elvárásokat, melyeket felsőbb körökből kaptak. Ezeknek a tapasztalatoknak a hatására a szakemberek kérdései is megváltoztak és arra irányultak, hogy az egyéni szükségletek, a szolgáltatások és a közösség hogyan kerülhetnek összhangba. Az egyénközpontú megközelítés úttöröinek rá kellett jönniük, hogy nem elég a társadalmi integráció. A jó és tartalmas kapcsolatok kialakítása és megtartása nem csak a fogyatékos személyek számára problematikusak, de a közösség más tagjai számára is, ezért a társadalmi integritás kialakítását helyi, közösségi szinten kezdték el. Ahogy ez a támogató rendszer egyre inkább szélesedett, úgy tudtak helyet készíteni a szolgáltatások átalakításának is. John O'Brien (1987) fogalmazta meg azt az öt dimenziót, amelyek alapján a szolgáltatásokat érdemes újra gondolni: közösségi jelenlét, a választás lehetősége, tisztelet, alkalmasság, közösségi részvétel.

Az 1970-es évek végétől Amerikájában lassan eltolódtak a hangsúlyok, és a szakmai közösségek kérdései lassan a szolgáltatások helyett az egyénre kezdtek irányulni. Az egyik legjelentősebb kérdéssé vált, hogy mi történik a fogyatékos személyekkel, akik a rendszerben vannak, ha a jelenlegi szolgáltatások nem változnak? A szakmai közösségek munkájának köszönhetően kezdett alakot ölteni a személyközpontú megközelítés és annak különböző irányzatai. Ezeknek alapértékei megegyeznek egymással, a különbség, hogy a klienscsoportok szükségleteihez alkalmazkodva dolgozták ki a módszereket. A fókuszban azonban mindig a választás szabadsága, a deperszonalizáció kerülése, kapcsolatok építése és erösítése, személyre szabott támogatás álltak. Ezek az értékek különösen hangsúlyosak, hiszen a szolgáltatást nyújtó személyek látásmódja meghatározza a szolgáltatás színvonalát. Ezért az eljárásmód és a keretek megváltoztatása helyett a személyzet látásmódját kell átformálni, hogy képesek legyenek a diagnosztikus címkéken és az intézményi kereteken kívül is gondolkozni, és a szolgáltatásban résztvevő személyek erősségeit előtérbe hozni (O’BRIEN és O'BRIEN, 2000).

A tradicionális, rehabilitációs paradigma a fogyatékosságot, a diagnózist helyezi a középpontba, és így egyre nehezebb és nehezebb elválasztani a személyt és fogyatékosságát. A fogyatékosságot pedig problémaként azonosítani. Amikor problémákról kezdünk el gondolkodni, akkor automatikusan megoldási lehetőségeket, professzionális segítőket és szolgáltatásokat kapcsolunk hozzájuk. Ugyanakkor ez a gondolkozásmód és intézményi szemlélet megnehezíti, hogy meglássuk az értéket és a potenciált azokban, akik a szolgáltatásokat igénybe veszik. Ezzel szemben az egyénközpontú megközelítés vallja, hogy minden ember - akár van valamilyen fogyatékossága, akár nincs, ugyanazokkal az alapvető szükségletekkel rendelkezik. A különbség csupán az, hogy a fogyatékos személyek számára sokszor nincs meg az a fokú függetlenség, mely képessé teszi őket arra, hogy megteremtsék 
azokat a kereteket és szituációkat a maguk számára, melyek a szükségletek betöltéséhez kellenek, ezért segítségre van szükségük. A cél, hogy a szolgáltatások és a közösség tagjai meg tudják teremteni azokat a feltételeket, melyek segítségével az egyén ki tudja bontakoztatni saját képességeit, és a közösség hasznos tagjává lehet (BROST és JOHNSON, 1982:6-7).

A módszerek alkalmazása során a tapasztalat megmutatta, hogy az alulról szerveződő folyamatok nem elégségesek a rendszer megváltoztatására, újra formálására, hogyha ehhez nem kapcsolódik felülről jövő politikai támogatás. Az 1992 utáni fejlődés több irányba tart. Vannak, akik a rendszer oldaláról próbálnak fejlesztéseket eredményezni, vannak, akik a családok támogatására és megerősítésére helyezik a hangsúlyt, és vannak, akik az ellátóiszolgáltatói szféra lehető leghatékonyabb müködésén dolgoznak. Minden fejlödési irányzat célja a fogyatékos személyek önálló életvitelének elömozdítása, de a rendszer más-más elemei szempontjából közelítenek, ami nagyobb rálátást, több lehetőséget biztosít annak optimálisabbá tételére. Mivel a közösség, a személyek, a családok, a szolgáltatók gyors ütemben változnak, ezért az egyénközpontú szemléletmódnak állandóan készen kell állnia arra, hogy ezekhez a változásokhoz képes legyen rugalmasan alkalmazkodni. Erre a különböző irányzatok eltérő gyorsasággal tudnak reagálni, de a felmerülő igények prioritást élveznek. (O’BRIEN és O’BRIEN, 2000)

\section{Természetes támaszrendszer és annak szerepe}

Az egyénközpontú megközelítés az egyes emberre, és annak természetes támaszrendszerére helyezi a hangsúlyt. Arra hívja fel a figyelmet, hogy a családnak, a közvetlen környezetnek megtartó ereje van. A segítség jelentősége és feladata, hogy a személyben rejlő potenciált képes legyen előhozni és kibontakoztatni. Az egyénközpontú tervezést családi, közösségi támogatás nélkül lehetetlen elkezdeni, hiszen a tapasztalatok szerint, a változás motivátorai elsősorban a családokból kerülnek ki. A motivátor ${ }^{3}$ az a személy, aki a változás hajtómotorja. Teljes mértékben elkötelezett a fogyatékos személy életében meghatározott célok és tervek felé, bátorítja a folyamatban résztvevőket arra, hogy ők is hasonlóan tegyenek. A motivátor feladata, hogy a megvalósítási folyamat a facilitátorok jelenléte nélkül is tovább müködjön. Ez egyrészt nagy erőssége, másrészt nagy gyengesége ennek a tervezési folyamatnak, hiszen Magyarországon nincs egy olyan széles körben elterjedt önkéntes, vagy közösségi bázis, amely be tudná tölteni ezt a szerepet azok számára, akik család nélkül, intézményi keretek között élnek, és nőttek fel, és ami választ tudna adni a tradicionális értelembe vett családi szerepek és kapcsolatok válságára. Minél mélyebbek a családi és személyes kapcsolatok, annál nagyobb az elköteleződés a jövőtervezés felé, és minél szélesebb ez a háló, annál gazdagabb lehetöségeket rejt magában a közös munka.

\section{MAPS módszer}

Ebben a részben módszertan sajátos értékeire, nyelvhasználatára, szerkezetére térek ki bővebben. A MAPS: Action planning ${ }^{4}$ módszer bemutatására, mely segíthet választ adni arra a kérdésre, hogy mi az, amiben ez többletet hozhat nekünk? Mik az alapvető eszközök és mögöttes filozófiák, melyek sikeressé tették ezt a módszert az amerikai és az európai kontinensen is?

\footnotetext{
${ }^{3}$ A motivátor kifejezést az eredeti angol „,motivator” szóból vettem át. Habár a magyarban ez nem használatos kifejezésezés, de jóval többet jelent, mint egyszerüen segítséget nyújtani. Azt jelenti, hogy valaki aktívan tevékenykedik a változások elömozdításában és másokat is lelkesít arra.

${ }^{4}$ MAPS: Action planning - MAPS (térképek) Cselekvési terv
} 


\section{Mi az álmod? - „A holdra akarok menni.”}

Az egyénközpontú tervezés és módszer mindig egy egyszerü álommal indul. Ez az álom nem a szakember álma, hanem azé a fogyatékos személyé, akivel együtt dolgozunk. Azt gondolom, hogy már ezen a ponton sikerül valami jelentőségteljesen újat adnia a szakma számára az egyénközpontú megközelítésnek. A határokat nem a segítő szakember eszközei húzzák meg, hanem a személy, és annak természetes támaszrendszerének erőtartalékai. Ez egyrészt nagy megkönnyebbülést, másrészt óriási felelősséget hordoz magában, hiszen tisztában kell lennünk azzal, hogy a tervezésben résztvevők számára mi az, ami belefér, és mi az, ami már nem. Ha ezzel tisztában vagyunk, jó esélyünk van arra, hogy egy álom a szemünk elött tud realitássá válni. De ahhoz, hogy erre az átalakulásra igazán felkészültek legyünk, szükségünk van arra, hogy megfogalmazzuk az egyénközpontú módszer által használt eszközöket és mögöttes értékeket.

\section{Alapvető értékek, eszközök és szereplők}

Az egyénközpontú megközelítés nem csak módszertanban, de nyelvhasználatban is eltér a tradicionális gondolkozásmódtól, ezért szeretném ezeknek a fogalmi kereteknek tisztázásával kezdeni. Azért is tartom ezt fontosnak, mert ezek a nyelvi eszközök, kifejezésmódok is szoros összefüggésben állnak az egyénközpontú elmélet látásmódjával, központi értékeivel, és az általános módszertan alapvető eszköztárával.

\section{A fogyatékos személy egyenértékü tagja a közösségnek és társadalomnak}

Az egyénközpontú megközelítés lehetőséget ad arra, hogy a fogyatékos személyek társadalmi megítélésre is hatással legyünk. A cél, hogy a függő helyzetből elmozdítsuk őket állampolgári szerepük megélése felé. Ezt az eszközt használhatjuk arra, hogy lebontsuk a meglévő rossz társadalmi beidegződéseket a fogyatékos személyekkel szemben, és lehetőséget adjunk számukra, hogy megéljék a hasznosságukat a közösség szintjén is. Amint a normalizációs elv is kimondja, nem csupán a megfelelő életkörülményeket kell számukra biztosítani, de a társadalmi megbecsülést, pozitív szerepeket is, mind egyéni, mind szolgáltatói szinten.

\section{Közérthetö nyelv}

Az egyénközpontú megközelítés nem a segítő szakmát vagy rendszereket szeretné kiszolgálni, hanem a fogyatékos személyt, és annak természetes támaszrendszerét. Ezért a segítő folyamatban olyan nyelvezetet kell használni, ami mindenki számára érthetö. A diagnózisok és szakszavak helyett az egyén képességeire és céljaira kerül a hangsúly, ennek megfelelően alakul a beszéd stílusa, szókincse és a találkozók hangvétele. A vizuális eszközök alkalmazása is elösegíti a találkozón elhangzottak minél pontosabb megértését és rögzítését. A cél a közös gondolkozás lehetőségének megteremtése, melynek alapvető feltétele, hogy mindenki számára befogadhatók legyenek az elhangzott információk. Fontos, hogy a lényeges elemeket többször is kiemeljük, világos célt fogalmazzunk meg, és az ehhez vezető lépések mindenki számára egyértelműek legyenek. Ez a kommunikációs technika lehetőséget ad arra, hogy félreértések és tisztázatlan helyezetek nélküli, eredményes találkozásaink legyenek a résztvevőkkel.

\section{Facilitátorok}


A facilitátor központi szereplöje a MAPS módszertanának. Rendkívül összetett a feladata, már személye önmagában értéket képvisel. A megfelelö facilitátor hiányában az egész munka kimenetele kétségessé válik. Ennek megerősítéseképpen visszatérnék a Holdas példára. A jó facilitátor nyitott az álmokra, a fókusz személy elképzeléseire. Hagyja, hogy ne a saját elképzelései befolyásolják, azzal dolgozik, amit a fókusz személy be akar hozni a folyamatba, még akkor is, ha először a valóságtól nagyon elrugaszkodottnak tünik.

A facilitátor kifejezést a szociális munkában ritkán alkalmazzuk, viszont a személyközpontú megközelítés szókészletében kiemelt szerepet kap. A facilitátor az a személy, aki elösegíti a folyamatok megfelelő müködését a csoporton belül. Megteremti azokat a körülményeket, bizalom, nyitottság, tisztelet, motiváltság -, melyben a csoport tagjai kibontakoztathatják képességüket és kreativitásukat egy közös cél definiálása és megvalósítása felé. A facilitátor felelössége a csoportfolyamatok felismerése, irányban tartása, és a tagok motiválása. Beth Mount (1990) 5 irányelvet fogalmaz meg kézikönyvében, amelyek mentén a facilitátorok eredményes munkát végezhetnek:

Nyitottság: A facilitátoroknak nem az a szerepe, hogy megtanítsák az embereket arra, hogy mit kellene csinálniuk, hiszen mindenki tudja, hogy mire lenne szüksége ahhoz, hogy jobb élete legyen. A facilitátor feladata, hogy teret és lehetőséget adjon mindenki számára, hogy megfogalmazza, kimondja a benne lévő gondolatokat, vágyakat, célokat. Ez a figyelem megadja a lehetőséget arra, hogy ne csak egy személy, de akár egy egész közösség életében változás induljon meg.

Kreativitás: Sokszor a megfogalmazott álmok, elképzelések nagyon távolinak, megfoghatatlannak tünnek. Mit kezdjünk azzal, amikor egy Down Szindrómás kisfiú a holdra szeretne menni? Hogyan lehet az ebben rejlö lehetőségeket kiaknázni, és a közösség segítségével életre hívni? Hogyan szerezhet magának barátokat az az autista kisfiú, aki most kezdi az iskolaévet integrált intézményben? A facilitátoroknak nagy kreativitásra van szüksége, hogy az álom és valóság közötti távolságot le tudják csökkenteni.

Elkötelezödés: Azokat az értékeket, melyek nincsenek meg bennünk, nem tudjuk tovább adni. Az elköteleződés pedig az egyik legfontosabb mozgatórugója ennek a módszernek. A facilitátor feladata, hogy a kitüzött álom, cél mellett elkötelezettekké tegye a csoport tagjait, hiszen annak megvalósítása akár hosszú hónapokba is telhet, rengeteg nehézséggel járhat, de képessé kell tenni a közösséget arra, hogy az elköteleződés erősebb legyen, mint a csalódástól való félelem.

Felfedezői attitüd: Értékek és lehetőségek felkutatása. Ez nem azt jelenti, hogy a nehézségeket, problémákat nem kell reálisan értékelni, de minden lehetőséget meg kell ragadni arra, hogy a képességekre felhívjuk a figyelmet, ezzel is megerösítve a pozitív énképet. Ez talán a szociális szférában dolgozók számára jelent nagy kihívást, hiszen a szakma alapvetően feladat és probléma-orientált.

Közösségépités: Már a jövőtervezés folyamata önmagában a közösség élményének megerősítésére és megélésére szolgál. Célunk, hogy a csoport tagja ne csak az egymás iránti elköteleződésben erösödjenek meg, de abban a tényben is, hogy együtt elérhetik a kitüzött céljaikat. Ez a folyamat a természetes támaszrendszer bövülését és a közösségi részvétel növekedését is eredményez(het)i.

\section{A facilitátor feladatai:}

Megteremteni a körülményeket a változásra 
Ahhoz, hogy hosszú távú, igazi változások jöjjenek létre az egyes személy életében, ahhoz szükség van a természetes támaszrendszer támogatására. Fontos, hogy azok az emberek, akikkel a fogyatékos személy mindennapi élete során találkozik, képesek legyenek felismerni és elismerni a képességeit, és ajándékait, amelyekkel a közösség müködéséhez hozzá tud járulni. A jövőtervezésben résztvevő személyek részéről fontos az elköteleződés a közös cél és annak megvalósítása felé, és ha ez lehetséges, akkor a tágabb környezetben lévő segítő szervezet támogatása is. A facilitátor szerepe, hogy mérlegelje, hogy az elköteleződés, és a közösségi részvétel mennyire megvalósítható. Ha a megvalósítás esélye csekély, akkor újra kell gondolni a folyamatot, és megfogalmazni a szükséges változásokat.

- A tanulási folyamat instruálása

A facilitátor számára szükséges olyan eszközök ismerete, mely elősegíti a csoport számára az információk kezelését, rendezését. Képessé teszi őket arra, hogy komplexen vizsgálják meg az életükben lévő kihívásokat, és hogy mit lehet ezekkel tenni. Erre nem csak elméleti, de gyakorlati útmutatást is nyújtanak a módszertani ajánlások. Rengeteg olyan önismereti és kommunikációs eszközt használ a egyénközpontú megközelítés, melyeket módszerből függetlenül is alkalmazni lehet.

\section{A csoport közösséggé válását elösegiteni}

Már maga a tervezési folyamat is a része annak, hogy a közösség élményét meg lehessen élni. Fontos, hogy ennek a kialakulását elősegítsük azzal, hogy formális megbeszélések helyett a csoport felszabadultan, egymásra odafigyelve haladjon elöre. A közösségi összefogásban hatalmas erő van, nem véletlen az, hogy minden társadalmi változás és fejlődés segíti a hosszú távú elkötelezödés fenntartását. Az egyénközpontú megközelítés alapvető célja, hogy hosszú távú változások történjenek az egyén és környezete életében. Ehhez viszont szükség van a csoport mély elköteleződésre a kitüzött célok mellett. A facilitátor feladata, hogy képessé tegye a csoport, vagy közösség tagjait arra, hogy a találkozók befejeztével önállóan is folytatni tudják, amit elkezdtek, és hozzásegítsék a fogyatékos személyt tervei elérésében. Ugyanakkor a záró alkalom nem a teljes elengedést jelenti. Fontos az utánkövetés, a változások mértékének és irányának vizsgálata, ha szükséges, felülírni azokat, és új célok mentén menni tovább.

\section{A fókusz személy}

A szociális munkában ezt a személyt kliensnek hívjuk. Ö a célja, és középpontja a tervezési folyamatnak. Ennek a pozitív kifejezésnek a célja szintén az egyénközpontú megközelítés elveivel cseng össze. Nem a fogyatékos személy hiányosságaira, problémáira hívja fel a figyelmet, hanem arra a tényre, hogy a segítséget igénylő személy nincs egyedül ebben a folyamatban. Körbe veszi őt a családja, barátai, a professzionális segítők, és mindenki azon dolgozik, hogy az együtt kitüzött célokat megfogalmazzuk és megvalósítsuk, miközben megerősítjük és tudatosítjuk a benne rejlő értékeket. A módszer további szereplőit összefoglalóan természetes támaszrendszer tagjainak nevezzük.

\section{A MAPS felépítése és müködése}


Az eddigiekben felmértük azokat az egyénközpontú megközelítés módszertanához nélkülözhetetlen értékeket és szereplőket, melyek az egész alapját adják. Ezeknek a hiányában nem tudjuk elkezdeni használni a MAPS-et. A következőkben részletesen végigvesszük az egyes lépéseket, és azoknak szerepét abban, hogy hatékonyan fel tudjuk mérni, hogy mi a fókusz személy álma, és a természetes támaszrendszer a facilitátor segítségével hogyan tud elköteleződni ennek az álomnak a beteljesítésére. (Ennek eredeti angol nyelvü forrása az irodalomjegyzékben megtalálható.)

A MAPS módszertani ajánlása 8 olyan alapvető elemet nevez meg, melyek nélkül nem beszélhetünk autentikus értelemben vett MAPS-ről.

1. Két facilitátorral dolgozik: az egyik a házigazda szerepét tölti be, a másik az események vizuális rögzítésért felelős

2. Az alkalmak vizuális rögzítése: fontos, hogy a megfelelő eszközök- színes tollak, ceruzák, kiemelök, lapok biztosítva legyenek. A színek segítenek a részfeladatok és szerepek elkülönítésében.

3. Bensőséges közeg kialakítása- az alkalmak 'otthonossá' tétele. Étel, ital, informális atmoszféra megteremtése.

4. A fókusz személy életének főbb szereplői mind legyenek jelen, aktívan vegyenek részt a folyamat alakításában.

5. A fókuszban lévő személy, testvérei, barátai szintén legyenek jelen, és aktív közremüködésükkel segítsék elő a folyamatot.

6. A központi kérdés, melyről mindenképpen beszélni kell: Mit szeretne a fókusz személy és annak családja?

7. Fontos, hogy megállapodás szülessen a legközelebbi találkozó időpontjától.

8. Konkrét cselekvési terv készítése 
A MAPS müködését leggyakrabban egy körrel szokták ábrázolni. A körben 8 kérdés helyezkedik el, melyeknek sorrendje nem kötött, de szükséges, hogy az alkalmak alatt az összes kérdést dolgozzuk ki. A sorrend kialakításához a facilitátorok érzékenysége is szükséges, képeseknek kell rá lenniük, hogy felmérjék, hogy melyik pontra mennyi idő szükséges, és annak végeztével hova kell tovább lépni.

A módszertani füzet a facilitátorok számára fontos alapszabályokat rögzít:

- A facilitátoroknak nem szükséges, hogy előzetes ismeretség legyen köztük és a fókusz személlyel, vagy annak családjával. Viszont a MAPS felépítését és müködését rendkívül alaposan ismerniük kell.

- Elengedhetetlen számukra, hogy teljes vállszélességgel álljanak az inklúzió mellett. Hinniük kell, hogy mindenki számára elérhető és kívánatos, ez alól nincs kivétel.

- Jó hallgatónak kell lenniük, aki képes arra, hogy meghallja mások fájdalmát, anélkül, hogy rögtön tanácsokkal és megoldási javaslatokkal álljon elö.

- Értő figyelemmel való hallgatás. A csoportban elhangzó információkat képesek legyenek a cselekvési tervbe beépíteni. Meglátni az összefüggést a részek között, hogy azok teljes egésszé állhassanak össze a folyamat végére.

- Fontos, az időkeret tisztázása az alkalmak kezdetén. Ez fontos a csoport tagjai számára, hiszen így mindenki számára tervezhetővé válik az együtt töltött idő. (Kisebb csúszások természetesen lehetségesek a tagok igényeinek és flexibilitásának megfelelően).

Az egyénközpontú tervezés több módon kezdödhet. A képzett facilitátorok dolgozhatnak alapvetően egyénközpontú-profilú intézményekben, alapítványokban vagy más segítő szakmában is. A megkeresés általában a család részéről érkezik, vagy egy intézmény, bentlakásos, vagy oktatási-, veszi fel a kapcsolatot a facilitátorokkal, vagy koordinátorukkal. Segítséget kérhetnek a változások megkönnyítésében, elindításában, a terv elkészítésében, de az is lehet, hogy a család egyszerüen csak egy olyan helyzetben ragadt, amelyböl nem találnak egyedül kiutat. Az első találkozás szükebb körben történik, melynek célja a fókusz személy történetének megismerése, és azoknak a személyeknek az összeállítása, akiket a tervezés folyamatába szeretnének behívni. Fontos, hogy a meghívás a fókusz személyen, vagy annak családján keresztül történjen, ez is már a képessé tevést, az aktív részvételt erösíti a csoport tagjaiban. Közös döntés alapján kell megszületnie az első találkozás idejének és helyének. Az egyénközpontú szemlélet képviselői általában bátorítják a résztvevőket, hogy a saját otthonukban szervezzék meg a találkozókat, ha ez számukra a legkényelmesebb megoldás. 
A kezdő alkalommal a facilitátorok már a csoport érkezése előtt megkezdik a helység elökészítését. A székek félkörben, körben, kényelmesen elhelyezve, étel-ital kirakva, a vizuális eszközök elökészítve, így várják az érkezőket. Nyitókörrel kezdődik az alkalom, melynek lényege, hogy a jelenlévő személyek bemutatkozzanak, és meséljék el, hogy milyen kapcsolatban állnak a fókusz személlyel. Már ekkor el lehet kezdeni a vizuális eszközök használatát, és kapcsolati ábrán felrajzolni, hogy a támaszrendszer megjelent tagjai hogyan kapcsolódnak egymáshoz.

A találkozók hossza a résztvevőktől függ. Vannak, akik egy napot szánnak a tervezés folyamatára, és közben nagyobb szüneteket tartanak. Vannak, akik a 2-3 alkalomra bontják szét a folyamatot. Ebben az esetben a facilitátorok előzetesen megbeszélik, hogy hol lenne érdemes abbahagyni, és ezekhez a keretekhez igazítják a csoportmunka folyamatát.

A MAPS-et két nagyobb részre szokták bontani. Az első rész a módszer rövid bemutatása után a fókusz személyt helyezi a középpontba. Személyes élettörténetét, a megjelent tagokkal való viszonyát, jelenlegi helyzetét, álmait és nehézségeit. Sok benne az érzelmi munka, ezért fontos, hogy még az alkalom elején kialakuljon a bizalommal teli légkör. A második rész már sokkal inkább a cél(ok) megvalósítására irányul. Hogyan lehet azokat elérni? A fókusz személy és a támaszrendszer tagjai milyen feladatokat tudnak magukra vállalni az álmok elérése érdekében?

A következő részben vázolni fogom egy MAPS alkalom felépítését, a kérdéseket melyekre a beszélgetés folyamata épül. Ehhez a 2013-ban, a NJCIE (New Jersey Coalition for Inclusive Education) gondozásában kiadott MAPS kézikönyvet veszem alapul (Plotting Your Course: A Guide to Using the MAPS Process for Planning Inclusive Opportunities and Facilitating Transitions) (Internetről letölthető PDF változata az irodalomjegyzékben megtalálható.)

\section{ELSÖ RÉSZ}

\section{Mi az a MAPS?}

A MAPS mozaikszó, azt jelenti: Making Action Plans (Készítsünk akcióterveket). Az angol eredetiben a map szó több mint egy mozaikszó, konkrét jelentése is van, a mindennapi életben is használt kifejezés, azt jelenti, hogy térkép. Ezzel a kérdéssel indul az első alkalom? Mire való egy térkép? Erre viszont magyar nyelven is rá lehet vezetni a jelenlévőket, hiszen biztosan lesz, aki ismeri a jelentését.

A térkép hasonlat ideális keret arra, hogy összefoglaljuk a módszer lényegét. A mögöttes gondolat könnyen értelmezhető mindenki számára. A célunk az, hogy a jelenlegi helyzetből közös erővel egy új állapotra jussunk el. A beszélgetések során a fókusz személy, és a természetes támaszrendszer erősségeit, gyengeségeit térképezzük fel, hogy ez alapján egy olyan tervet, vagy lehetséges útvonalat tudjunk készíteni, mely segít elérni a kitüzött célt. 
2. Mi a történet? (ez akár egybe is folyhat a következő pontban tárgyalt álom kérdéssel)

Arra próbáljuk megtalálni a választ, hogy azok számára, akik ismerik a fókusz személyt, mit jelent a vele való kapcsolat? Melyek a leglényegesebb dolgok, melyek velük, közösen történtek, történnek. Fontos, hogy nem esettanulmányt szeretnénk felvenni, hanem arra szeretnénk helyezni a hangsúlyt, hogy a természetes támaszrendszer mit szeretne vele kapcsolatban megosztani. Amire viszont érdemes gondolni, hogy szabjunk időkorlátot a felszólalók számára, hiszen a történetmesélés alatt könnyen kifolyhat az idő a kezünk közül, ha nem figyelünk. A vizuális rögzítése a különböző történetszálaknak szintén nagyon hangsúlyos, használhatunk képeket, rövid összefoglalókat, érdemes az egyes történeteket külön színnel jelölni. Érdemes a facilitátornak minden történet után röviden összefoglalni a hallottakat, hogy megbizonyosodjon róla, hogy jól értelmezte a tényeket és a fontosabb részeket. A helyesírásra is figyeljünk oda!

Ezen a ponton nagyon sok pozitív és negatív érzelem is megnyilvánulhat, ezért a facilitátorok számára kifejezetten fontos, hogy a lehetö legempatikusabb módon hallgassák a történeteket, és bíztassák a csoport többi tagját is erre.

\section{Mi az álmod?}

Ez egy különösen sarkalatos pontja a beszélgetésnek. Azért is, mert ezt a kérdést a professzionális segítő munka során nem igazán szokta senki sem feltenni. Különösen egy szakmai beszélgetés keretében viheti ez a kérdés irracionálisnak tünő szintre a kommunikációt, viszont jelen helyzetben kulcsfontosságú. Szintén a facilitátor dolga érzékelni, hogy mikor van itt az ideje ennek a kérdésnek, hiszen ahhoz, hogy erről őszintén tudjunk beszélgetni, a megfelelő atmoszférára, elfogadó attitüdre szükség van, Ha ez nincs meg, akkor elöször érdemes azon dolgozni, hogy ez kiépüljön a csoportban. 'Ha nem tartanának vissza, sem anyagi sem más problémák, akkor mi lenne az, amit szeretnél? Mi az, amiben titkon reménykedsz?' Ezt a kérdést sokszor nagy csend követi, de ne féljünk ettől! Adjuk meg a csoport tagjai számára, hogy megfogalmazzák és kimondják az álmaikat. Ez az egész folyamat szíve, ezért, ha sietettjük, az egész munka értelmét vesztheti. A MAPS lényege, hogy ezekre az álmokra és tervekre képessé tudjuk tenni a csoport tagjait. Rajzok készítése, kulcsszavak kiemelése ebben a szakaszban is nagyon fontos! Az amerikai tapasztalatok azt mutatják, hogy azok a személyek, akik nem beszélnek, ök is meg tudják fogalmazni ezt a családjuk segítségével. Ilyenkor érdemes olyan formában feltenni a kérdést, hogy; Mit gondolsz, ha xy beszélni tudna, akkor mit mondana, mi az álma?

4. Mi a rémálmod, a félelmed ezzel kapcsolatban? 
Ennek az identifikálására azért van szükség, hogy elkerülhető legyen. Ezeknek a megfogalmazása sokszor az első lépés a megoldás felé. Tapasztalatok szerint nem a gyermekeik érdemjegyei foglalkoztatják leginkább a szülőket, hanem hogy mi lesz velük, ha már ök nem élnek. Vagy hogyan találhatnának barátokat? Hogyan lehet elkerülni, hogy intézményben kerüljenek? A fogyatékos személy és családja sokszor ki nem mondott konfliktusai az őket segítő szakemberekkel ezen a ponton sokszor feloldást nyernek. Sok olyan esetröl számolnak be a módszer használói, ahol az iskola és a család közötti konfliktusok ebben a szakaszban kerültek rendezésre, és ellentétes oldalon álló harcosok felismerték, hogy mennyi közös van bennük.

Ez után szünet következik. A második részben az érzelmek után gyakorlatiasabb kérdésekre tolódik a hangsúly, ahogy az akcióterv kidolgozása felé közeledünk. Ha nem egyben szeretnénk megtartani az alkalmat, érdemes egy rövid zárókörrel összefoglalni az addig történteteket, teret hagyni arra, hogy a résztvevők visszajelezzenek az aktuális lelki állapotukról, és a pozitív érzelmekkel zárni az alkalmat. Fontos, hogy egyezzünk meg a következő találkozó helyszínében és időpontjában. 


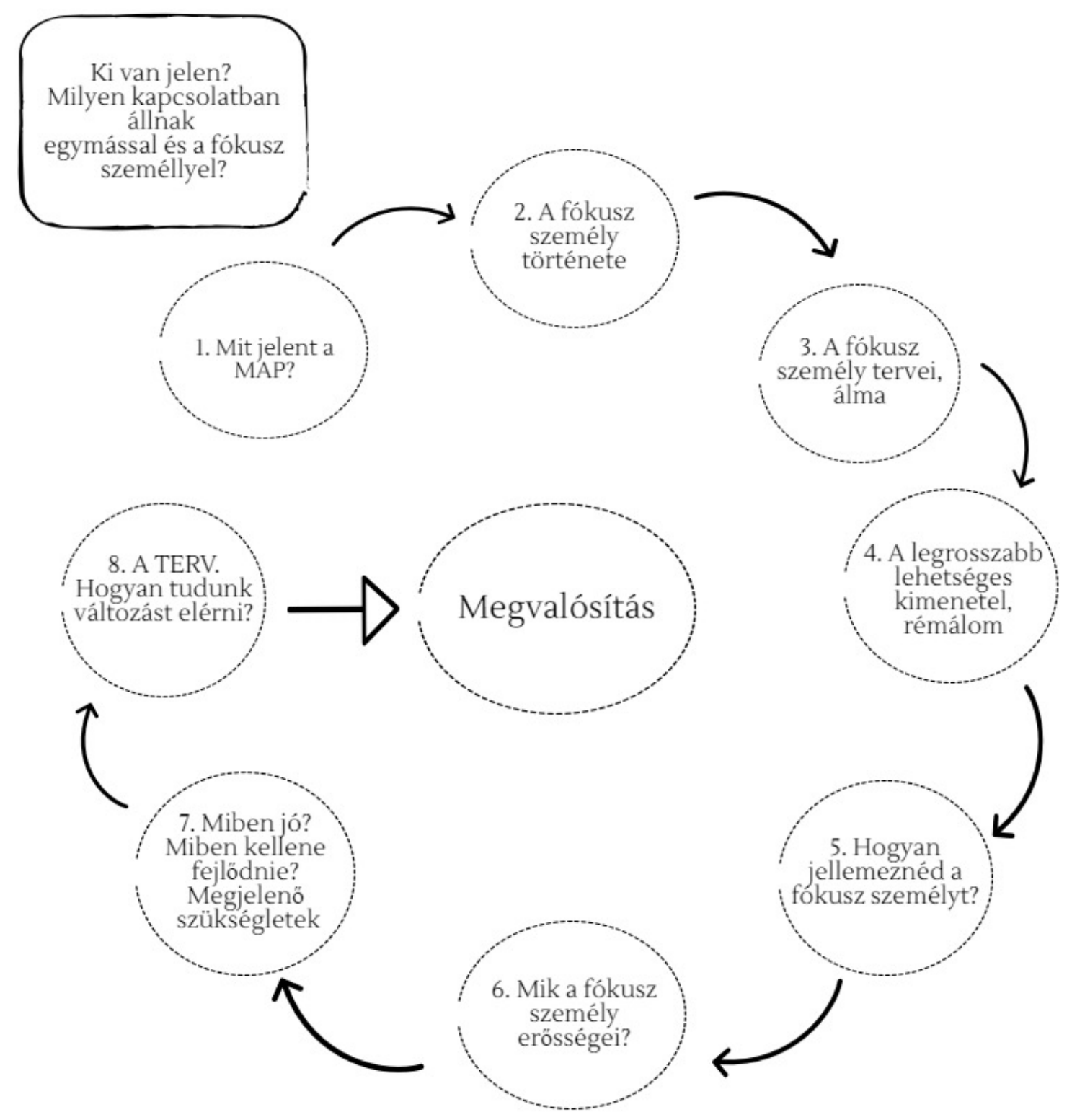

Forrás angolul: http://www.inclusion.com/artcommonsensetools.html 


\section{MÁSODIK RÉSZ}

\section{Kicsoda a fókusz személy?}

Az első rész után mozgalmasabb, kissé játékos formában folytatjuk. A fókusz személy körvonalát egy nagy ív papírra rajzoljuk, majd a csoporttagok post-it lapokat és íróeszközt kapnak. A feladat, hogy mindenki leírja az egy szóban vagy mondatban, ami először eszébe jut róla. Ez azért is fontos, hogy reális képet kapjunk az illetőről. Ha úgy érezzük, hogy hiányos a kép, akkor van lehetőséget többet írni. Érdemes megkérdezni, hogy ezelött milyen más jelzőkkel illették a fókusz személyt, más környezetben, esetleg más esetmegbeszélön. Lehet, hogy drasztikus különbségekkel fogunk találkozni! Ezeket is érdemes felírni, de a csoporttagok szavaitól, mondataitól elkülönítve.

2. Mik a fókusz személy erösségei és különleges tehetsége?

Ez sokszor összefonódik az előző kérdéssel, de itt már konkrétabban az erősségekkel dolgozunk. Ennek a célja, hogy a fókusz személy jó tulajdonágai és képességei külön elismerésre kerüljenek, megerösítést nyerjen, hogy mennyire értékes személynek tartjuk öt, mint személyt.

3. Miben jó a fókusz személy? Mi az, amit szívesen csinál? Melyek a felmerülő szükségletek?

Ennek a listának az összeállítása abban segít, hogy nagyobb rálátásunk legyen a fókusz személy napi, heti ritmusára, kedvteléseire. Így kapunk teljesebb képet életének kisebb részleteiről is. Ezek készítik elő a szükségletekkel kapcsolatos kérdéseket. Mit kellene tennünk ahhoz, hogy megvalósuljon az álom, amiről a harmadik pontban beszéltünk? Mire lenne ehhez szükség? Mire lenne szüksége a támaszrendszer tagjainak? A professzionális segítőknek? Hogyan tudnánk jobban segíteni a fókusz személynek? Nagyon fontos, hogy a felmerülő szükségleteket képesek legyünk összehangolni, hiszen akkor tudunk leghatékonyabban részt venni a fókusz személy álmának megvalósításában, ha a saját szükségleteink be vannak töltve. Például, ha az anyuka talál arra időt, hogy kikapcsolódjon, feltöltődjön, akkor sokkal hatékonyabban tud jelen lenni fogyatékos gyermeke életében.

\section{Akcióterv}

Amikor a szükségleteket képesek vagyunk megfelelően kommunikálni, akkor ennek a folyamatnak a megoldási terv készítése természetes részévé fog válni. A MAPS eszköztárában különböző táblázatok találhatók, melyek elősegítik a programok helyének, időpontjának a tervezését, és hogy kinek a felelőssége, hogy az meg is valósuljon. Amikor megfogalmazódnak a konkrét elképzelések szükség lehet arra is, hogy új embereket vonjunk be ebbe a csoportba, olyanokat, akikre eddig esetleg nem gondoltunk! 
Az is lehetséges, hogy az akcióterv megvalósításához több emberre lesz szükség, mint gondoltuk, a természetes támaszrendszer, vagy más professzionális segítők bevonásával. Ha ez a kör nagyra tágul, vagy az akcióterv kibontakozása alatt kiderül, hogy azt át kell fogalmazni, akkor érdemes egy újabb MAPS alkalmat szervezni, hogy átgondoljuk a lehetőségeket. Ha ezek a változások nem merülnek fel, akkor is érdemes pár héten belül újra találkozni a csoportnak, hogy számba vegyék, hogy milyen elmozdulás történt a fókusz személy életében, és hogy a vállalt felelösségeket mindenki be tudja-e tartani.

\section{ZÁRÁS}

Fontos, hogy az alkalom végén foglaljuk össze, hogy mi is történt. Ebben a vizuális eszközök nagy segítségünkre vannak, megerősítik és felidézik a csoportban történt folyamatokat és lépéseket. A kézikönyv a facilitátorok számára javasolja, hogy ezeket a vizuális eszközöket egy kis ajándék keretében adják át a családnak. Cserepes növényt javasolnak, mely a növekedést, a fejlödést szimbolizálja.

A záró körben, a munka megköszönése után adjunk lehetőséget arra, hogy mindenki egy-két szóban vagy mondatban összefoglalja, hogy milyen érzéseik vannak az együtt töltött idővel, közös munkával kapcsolatban. (New Jersey Coalition for Inclusive Education, 2013)

A MAPS módszer szépsége, hogy nem önmagában álló egység csupán, hanem bővíthető, kiegészíthető. Lehetséges új eszközök bevonása annak érdekében, hogy még részletesebb képet kapjunk a fókusz személyröl, annak támaszrendszeréről és lehetőségeiről. A módszer Kanadába történő adaptálása és fejlesztése, 1989-ben Marsha Forest és Jack Pearpoint nevéhez füződik, Personal Futures Planning néven vált elterjedté. Célja nem csupán az iskolai integráció elösegítése, hanem bármilyen szükségesnek ítélt változás elősegítése a fókusz személy életében és annak közvetlen környezetében.

Ezeknek a pontoknak az alapján most már könnyebb magunk elé képzelnünk, hogy hogyan zajlott a MAPS alkalom a kisfiúval, aki a Holdra akart eljutni.

A fókusz személy álma, az volt, hogy a Holdra mehessen. A facilitátor ennek érdekében a természetes támaszrendszer megismerése és feltérképezése után az álom kibontására fókuszált. Hagyta, hogy a kisfiú saját szavaival írja körül, hogy mit is ért ez alatt pontosan. A beszélgetés során nyilvánvalóvá vált, hogy nem a Holdra szállás az igazi cél, hanem a fókusz személy ezzel fejezte ki, hogy mennyire szereti a csillagokat, és minél többet szeretne megtudni a világürről. Az álom kibontásával a természetes támaszrendszer képessé vált arra, hogy megértse, hogy mit szeretne a fókusz személy, és tervet tudtak készíteni arra, hogy ezt hogyan lehetne megvalósítani. Találtak egy csillagász klubot, ahova együtt mentek hol az apukájával, hol a testvérével. Az álom megvalósulásán túl a kisfiúnak további előnyei is származtak a módszer alkalmazásából. Nőtt a magabiztossága, jobban ki tudta magát fejezni, megfogalmazni a nehézségeit és vágyait. Mélyültek a családon belüli kapcsolatai, közös érdeklődési pontot talált más emberekkel, bővült a kapcsolati hálója, integrált részévé vált egy közösségnek. Ezek mind csupán a járulékos nyereségek voltak a konkrét álom elérése mellett! Gondoljunk bele, hogy mekkora segítséget nyújthat ez a módszer azoknak, akik új iskolába kerülnek, vagy új közösségbe. Az intézménytelenítés során a fogyatékos személyek újradefiniálásának folyamatában, és az integráló közösséggel való párbeszédben a talán nehezen induló párbeszédeket mennyire megkönnyíthetné, és a MAPS módszer csak egy a 
különböző technikák közül, mely arra épít, hogy személyre szabott segítséget tudjunk azon fogyatékos személyek számára, akik eddig kiszolgáltatott helyzetben voltak, minimális jogokkal és lehetőségekkel a saját életük irányítása kapcsán!

\section{A MAPS rövid elemzése:}

Az egyénközpontú tervezés több mint módszertani megközelítés. Látásmódot, értéket közvetít, mely szerint minden ember egyenlő, és minden ember képes arra, hogy pozitívan hozzájáruljon a társadalom és a közösség életéhez. Nem az ellátórendszerekre, hanem az egyénre és kapcsolataira épít, ezzel alapvetően újat hoz a fogyatékos személyekkel való segítő munkába, hiszen nem a tárgyai a munkának, hanem aktív résztvevői és alakítói annak. Szakemberek bevonásával, de nem szakemberek irányításával történik a jövőtervezés folyamata. A fogyatékos személyre és annak természetes támaszrendszerére épít, mely egyszerre erőssége és gyengesége is a személyközpontú tervezésnek. A tettre kész, aktív támogatói rendszerben hatalmas erőforrások rejlenek, ezért is van, hogy nagyon sok alapítványt és szervezetet olyan emberek hoztak létre, akiknek személyes élményük van a fogyatékossággal kapcsolatban. Az egyénközpontú tervezés megmozgatja a kreativitást, cselekvésre ösztönzi a résztvevőket és képes megteremteni a közösség, az összetartozás érzését. Ugyanakkor a család és a támogató közösség hiánya az ellenkező hatást éri el. Ha nincsenek mellettünk emberek, akik támogatnak és hisznek bennünk, akkor a lehetőségek helyett könnyü a problémákra fókuszálni, és elveszteni a változással kapcsolatos motivációt. Az intézményi keretek között nevelkedők számára sokszor éppen ezért nehéz célokat megfogalmazni, vagy a jövőről gondolkodni. Viszont pont számukra lenne a legfontosabb, hogy személyre szabott szolgáltatásokkal tudjunk előállni. Sajnos ez a módszer nem tud erre megfelelő megoldást adni, amíg nem alakul ki egy olyan erős, nyitott társadalmi réteg, mely képes arra, hogy hiányzó családból származó erőforrást pótolni tudja.

A veszélyek közül a nem megfelelő facilitátort emelném ki, hiszen az ö hiányosságaiból eredhetnek a legnagyobb problémák, negatív kimenetelek. Nem mindenki alkalmas erre a feladatra, ugyanakkor a megfelelő motivációval és értékekkel mindenki alkalmas lehet! A facilitátoroknak képeseknek kell lenniük arra, hogy felmérjék a fókusz személyben és a természetes támaszrendszerben lévő lehetőségeket, és érdekeltté tudják őket tenni abban, hogy a célok megvalósításában kitartsanak, azután is, hogy a találkozásoknak vége van. A facilitátorok dolga, hogy az általuk képviselt értékeket átadva szükségtelenné tegyék magukat a közösség számára, önmüködővé tegyék a projektet. Ezért lenne szükség arra, hogy a képzés és felkészítés során, nemcsak a módszert, de a mögötte húzódó értékeket is átadjuk.

Társadalmi szemléletformálás lehetösége az egyénközpontú megközelítés módszere által! A családok bevonása mellett szükség van a polgári, civil, önkéntes bázis használatára, hiszen a szülök, családtagok sokszor túlterheltek, saját elvárásaikba, álmaikba, kudarcukba ragadtak és nincs meg az az érzelmi és motivációs többlet, mely átvihetné a családot és a fogyatékos személyt ezen az időszakon és a tervekböl és álmokból konkrét cselekvés és életváltozás következne.

\section{Milyen aktuális dimenziói vannak az egyénközpontú szemléletnek hazánkban?}


Amikor elöször találkoztam az egyénközpontú megközelítéssel Csehországban, azt gondoltam - és ma is azt gondolom -, hogy valami nagyon értékes dologra bukkantam. Gyakorlatias, konkrétan alkalmazható eszközt ad a szakemberek kezébe és éppen az egyik legégetőbb kérdésre, a kitagolási folyamatra nyújthat olyan megoldást, mely jelentősen csökkentheti a nagyintézmények felszámolása körülötti feszültségeket. Segít kommunikálni a folyamat szereplöi között, segít felmérni az igényeket és a lehetőségeket is. Felhívja a figyelmet arra, hogy milyen nagy szükség van arra, hogy a természetes támaszrendszer tagjaiként felelősséget vállaljunk ebben a folyamatban, és valós szükségletekre reagáljunk.

A TASZ által megfogalmazott „Intézménytelenítés és közösségi lakhatás - Vitaindító munkaanyag, 22 pontban" felvázolt igényekre is képes reagálni a MAPS módszer, amennyiben a helyi viszonyokhoz alakítjuk. A kitagolás kapcsán a TASZ megfogalmazta azt a 22 pontot, melyet a folyamat kapcsán elérendő céloknak tartanak. Azt gondolom, hogy ez a módszer gyakorlati útmutatóként fogalmazódhat meg ezzel kapcsolatban, ugyanakkor érdemes kiszélesítenünk ennek a módszernek a használatakor a kitagoláson túlra is, hiszen útmutatóként szolgál arra, hogy hogyan könnyíthetjük meg az integráció folyamatát a fogyatékos személyek számára a közösségekbe. Néhány példát említenék, a teljesség igénye nélkül. Elösegítheti a fogyatékos személyek helyi közösségekben való integrálódását, megmaradását. A szabad választás lehetőségének megteremtését, egyéni igények szerinti lakhatás lehetőségének megteremtésének eszköze lehet, valamint a MAPS módszer segíthet a gondozásközpontú szemlélet lebontásában is. Az egyénközpontú megközelítés hatékony eszközként szolgálhat a lakók, munkatársak és a közösség felkészítésére is. A saját döntéshozatal támogatásának alapját adhatja. Fontos, hogy adoptáljuk a rendszert az itthoni sajátosságokra. Ahogy Nirje normalizációs elve és alapként szolgált Wolfensberger számára, úgy számunkra is jó példa lehet, mind a MAPS, mind az egyéb egyénközpontú módszerek alkalmazása. De arról nem szabad elfelejtkezni, hogy ezeket hozzáigazítsuk a hazai viszonylatokhoz, társadalmi, szociális és politikai folyamatokhoz.

\section{Mi lehet az oka annak, hogy nem valósul meg a módszer gyakorlatba való átültetése?}

Elöször is, a módszer ismeretlensége. Igaz, hogy Amerikában az egyénpontúság több évtizede jelen van, de mi csak most kezdünk szembesülni a létezésével. Ott is hosszú időbe telt mire általánosan elfogadottá vált. Szükség volt a szakemberek odaadó munkájára, a megfelelő kérdések feltevésére, és a nem müködő rendszerek felülírására. Nem egyszerü feladat, de nem is tartom lehetetlennek.

Sokat gondolkoztam, hogy ha ez a szemléletmód ennyire pozitív hatással van az emberek életére, akkor miért nem alkalmazzuk? Mi az, ami visszatart minket attól, hogy a fogyatékos személyeket képessé tegyük őket a céljaik megfogalmazására és elérésére? A kérdésemre Beth Mount segített megtalálni a választ, aki a PFP módszertani könyvében arról ír, hogy a szociális szakemberek az állam vagy a civil szektor által fizetett segítők, ezért elsősorban nem a fogyatékos személynek, vagy családjának dolgoznak, hanem elsősorban rendszereknek vagy intézményeknek. A rendszer által állított követelmények és elvárások sokszor felülírják az emberek álmait, és az alkalmazottak elszámolási kötelezettsége elsősorban a szolgáltatók irányába érvényesül.

Erre magyarországi az intézménytelenítés folyamata a 2000-es évek elején kiváló példaként szolgál. Verdes Tamás: A ház az intézet tulajdona (2009) cikkében részletesen taglalja, hogy az intézményi kultúra hogyan tartja fenn, és termeli ki saját igényei szerint a szolgáltatásokat. 
Ez a rendszerváltás után két igényből fakadt: a foglalkoztatási oldalon kialakult deficit megjelenéséből és a társadalmi szolidaritás meggyengüléséből. Habár az ezredfordulón megjelent a lakhatási szolgáltatások új modellje, az adaptáció során elveszett a mögöttes tartalom, és értékek, és a hangsúly az intézményen belüli, struktúrába ágyazott változásokra került, mely ismét a rendszer fenntarthatóságát helyezte a felhasználók érdekei elé. A civil szektor államra gyakorolt nyomása pedig nem bizonyult elégségesnek a mélyebb, szemléletmódbeli változások elindítására. Ez sajnos mind a mai napig így van, de talán a rendszerváltás idején felnövekvő generáció képes lesz a köztudat formálására és jogi és politikai dimenziók átalakítására használni meglévő erőforrásait.

A szükséges közösségi bázis hiánya, az intézményközpontú szemlélet túlsúlya. Ahogy az egyénközpontú tervezés kézikönyveit tanulmányoztam, világossá vált számomra, h megfelelö eszközök és képzés nélkül nem fog a módszer itthon meghonosodni. És a módszernél jóval többről van szó, hiszen a mögötte húzódó értékek és szemléletmód teszi különlegessé az egyénközpontú tervezést. A hangsúly az intézmények helyett az egyénre és a közösségre helyeződik, mely az államtól való függőség helyett a személyes kapcsolatok erejét használja. A módszer hátránya, ha nincs meg a megfelelő közösségi bázis, nincs család, vagy nincsenek közeli kapcsolatok, akkor nem lehet életképes. Viszont az utóbbi években már egyre nagyobb jelentősége van az önkéntességnek Magyarországon is, projektek épülnek az összetartás, a közösségi értékek és a társadalmi összefogás megerősítésére, mely megfelelő talaj lehet az egyénközpontú gondolkozásmód megerősítésére.

Ezeken felül még van néhány kevésbé jelentőségteljesnek tünő oka, de úgy gondolom, ezekkel mindannyian könnyen tudunk azonosulni. Idöhiány, prioritások felállítása, motiváció hiánya a változásra. Ezek mind olyan dolgok, melyekkel a mindennapi élet területein küzdünk. Hogy melyek azok a dolgok, melyek előnyt élveznek más dolgokkal szemben, hogy motiváltak vagyunk-e a változásra, vagy már könnyebb elfogadni, hogy vannak megmásíthatatlannak tünő helyzetek. Számomra ezek nagyon aktuális kérdések!

\section{Az egyénközpontú megközelítés előnye}

Az egyénközpontú megközelítés nem akar konkrét szociálpolitikai vagy szociális jogi eszközöket alkalmazva direkt belenyúlni a fogyatékos személyek megítélésébe, ugyanakkor célja, hogy a fogyatékos személy, és természetes támaszrendszere megerösödjön, és hatással legyen annak a közösségnek a müködésébe, amelynek részese. Ezért Magyarországon ennek a megközelítésnek az elterjedését nehezíti a tény, hogy a fogyatékos személyeknek még mindig nem sikerült „állampolgári státust” (VERDES, 2009) szerezniük. Az ellátásukról, lehetőségeikről, jövőjükről szóló diskurzusok még mindig róluk szólnak, de az esetek túlnyomó többségében sajnos nélkülük. Ennek megváltoztatásában a legnagyobb felelösségünk nekünk, szakembereknek van! Az önálló életvitel kialakítására és ösztönzésére ideális választ ad az egyénközpontú megközelítés, hiszen a módszer bázisát elsősorban nem a szakemberektől várja, hanem célja, hogy felkészültté tegye a természetes támaszrendszert és feloldja a hosszú évek óta bennünk lévő rendszerfüggőséget, melyet a hazai jogszabályok is erőteljesen erősítenek. Egységes álláspontra lenne szükség a kitagolás mellett. Így közösen lehetne képviselni azt a közösségek felé. A kettősség eltérő érdekek irányába húzza nemcsak a szakembereket, de a témában érintett más szereplöket is. Ez az ellentét viszont csökkenti a hatékonyságot. 
Az egyénközpontú megközelítés nem csak a személy saját erőforrásaira épít, hanem ebbe a folyamatba behívja annak természetes támaszrendszerét is. A teljes függetlenség helyett inkább egy biztonságos közeg megteremtése a cél, amikor a közösség tagjai együtt mozdulnak a fogyatékos személy céljai elérése érdekében. Mindenki hozzáteszi azt, amit fel tud ajánlani idejéből és lehetőségeiből. Van, aki csak heti egyszer elviszi és hazahozza a fókusz személyt. Van, aki az életének más területein vonódik be és lehetőséget biztosít arra, hogy integráltabb tagja legyen a közösségnek, vagy az általa meghatározott irányba képes legyen fejlödni. A cél az, hogy a fókusz személy álmainak, céljainak megvalósulását segítsük elö anélkül, hogy bárkit a kiégés felé terelnénk, mert túlvállalta felajánlásait. Ebböl a szempontból ki kell hangsúlyoznunk, hogy az egyénközpontúság fókusza a fogyatékos személyen van, de arra a facilitátornak és a közösség tagjainak külön hangsúlyt kell fordítaniuk, hogy a történet szereplöinek minden tagja megtalálja ebben az ő saját személyére szabott szerepet. Ez a szemléletmód nem ignorálja a fogyatékosság tényét, csupán áthelyezi a hangsúlyt a fogyatékosságról azokra a dolgokra, amelyekre a személy képes. Kettős cél jelenik meg: Bátorítani a fogyatékos személyt, hogy merjen célokat kitüzni maga elé, és segíti abban a természetes támaszrendszer tagjait, hogy megtanulják azt, hogy ebben a helyzetben hogyan lehet legjobban támogatni öt.

\section{Zárás}

Írásomat gondolatébresztőnek szánom. Arra hívom olvasóimat, hogy kezdjük el kiszélesíteni a látóterünket. Merjünk az ellátórendszer keretein kívül is gondolkozni. A szociális ellátások célja, hogy helyettesítőként szolgáljanak akkor, amikor a család, a közösség erőforrásai már elfogytak. Azt gondolom, hogy a természetes támaszrendszer rendelkezik olyan tartalékokkal, olyan erőforrásokkal, melyekkel talán még nem is vagyunk tisztában. A civil kezdeményezések promóciója, az önkéntes bázisok megszilárdítása, a családok megerősítése mind elöfeltételei annak, hogy mi is elinduljunk az egyénközpontú gondolkodásmód átvétele és alkalmazása felé, mely az integráció folyamatában minőségi ugrást biztosíthat mind a fogyatékos személyeknek, mind a fogadó közösség tagjainak, ezért mindannyiunk számára nyereség lehet ennek a szemléletmódnak és módszertannak a megismerése és alkalmazása.

\section{Irodalomjegyzék}

Bugarszki Zsolt, Eszik Orsolya, Szentkatolnay Miklós, Sziklai István: A nagy létszámú intézmények kitagolása és az önálló életvitel támogatása Magyarországon 2010-2011 http://tatk.elte.hu/file/CANIS 2011 zarotanulmany.pdf látogatva: 2017.10.25.

FOREST M. és PEARPOINT J. Common Sense Tools: MAPS and CIRCLES for Inclusive Education

Internetes forrás: http://www.inclusion.com/artcommonsensetools.html (Látogatva 2017.03.17.)

HATOS GY. (2007): Búcsú a normalizációs elv atyjától (Bengt, Nirje - 1924-2006). Gyógypedagógiai Szemle, 2007/2 155. oldal

KÁLMÁN ZS. - KÖNCZEI Gy. (2002): A Taigetosztól az esélyegyelőségig. Osiris Kiadó, 
Budapest

KISSNÉ SZENTMIHÁLYI M - PÓTI V: Fogyatékkal élő emberek (p. 79-97.) In: A láthatatlanság vége. Társadalomismereti szöveggyüjtemény. [Szerk.]: Gelsei Gergő - Gergely Vera - Horváth Vera - Rácz Márton. Bp. Alapítvány a Társadalomelméleti Kollégiumért, 2004. LÁNYINÉ Á (1976): A gyógypedagógiai pszichológia korszerű szemléleti kérdései. In: A gyógypedagógia alapproblémái szerk: dr Göllesz Viktor, Medicina, Budapest 1979.

LYLE O'BRIEN C. és O'BRIEN J. (2000): The Orginis of Person-Centered Planning - A Community of Practice Perspective. Responsive Systems Associates, Inc. (Internetes forrás: http://citeseerx.ist.psu.edu/viewdoc/download?doi=10.1.1.502.8388\&rep=rep1\&type=pdf Látogatva: 2017.02.10.)

MOUNT B. (1992): Person-centered planning: A sourcebook of values, ideas, and methods to encourage person-centered development. New York: Graphic Futures

MOUNT B. (1990): Making Futures Happen. A Manual for Facilitators of Personal Futures Planning. Metropolitan Council's DD Case Management Project

NJCIE (2013): Plotting Your Course: A Guide to Using the MAPS Process for Planning Inclusive Opportunities and Facilitating Transitions. New Jersey Council on Developmental Disabilities. Internetes forrás: $\mathrm{N} J$ Coalition for Inclusive Education honlapja: http://njcie.org/resources/ Látogatva: 2017.02.22., Az eredeti PDF elérhető itt)

O'BRIEN J. (1987): A guide to lifestyle planning, In B Wilcos and T. Bellamy, eds. A comprehensive guide to the activities catalog. Baltimore: Paul Brookes Publishing.

ROBERTS E. 60 Minutes Segment with Harry Reasoner http://mn.gov/mnddc/edroberts/sixtyMinutes.html (Látogatva: 2017.03.29.)

VERDES T. (2009): A ház az intézet tulajdona, A totális intézmények lebontásáról, humanizálásáról és modernizálásáról in Esély 2009/4 92-114.oldal

WOLFENSBERGER W és TULLMAN S. (1982): A brief outline of the principle of normalization. Rehabilitation Psychology, Vol 27(3), 131-145.

Intézménytelenítés és közösségi lakhatás- Vitaindító munkaanyag 22 pontban

https://tasz.hu/files/tasz/imce/22pont intezmenytelenites.pdf látogatva: 2017. 11. 01.

http://pcp.sonoranucedd.fcm.arizona.edu/resources/person-centered-planning-tools/map látogatva: 2017.11.30.

MAPS rövid módszertan: http://www.inclusion.com/artcommonsensetools.html látogatva: 2017.11.30. 